\title{
Capital Structure Dynamics of Listed Banks in Ghana
}

\author{
Anthony Kusi ${ }^{1,}$, , Joseph Yensu ${ }^{1}$, Kobina Eduful Aggrey ${ }^{2}$ \\ ${ }^{1}$ Institute of Entrepreneurship and Enterprise Development, Kumasi Polytechnic, Kumasi, Ghana \\ ${ }^{2}$ Bank of Africa Ghana Limited, Kumasi, Ghana \\ Email address: \\ anthonykusi61@gmail.com (A. Kusi),joseph.yensu123@gmail.com (J. Yensu), kobgrey@yahoo.com (K. E. Aggrey) \\ ${ }^{*}$ Corresponding author
}

\section{To cite this article:}

Anthony Kusi, Joseph Yensu, Kobina Eduful Aggrey. Capital Structure Dynamics of Listed Banks in Ghana. International Journal of Finance and Banking Research. Vol. 2, No. 5, 2016, pp. 167-177. doi: 10.11648/j.ijfbr.20160205.12

Received: June 20, 2016; Accepted: July 12, 2016; Published: August 22, 2016

\begin{abstract}
The aim of this paper is to provide a comprehensive review on Capital Structure Dynamics of Listed Banks in Ghana. The study examines the determinants of capital structure, the significance of performance on equity and leverage. Seven (7) Banks on the Ghana Stock Exchange were used for the periods 2005 to 2012 The fixed and random effect regression technique was used. The study found Asset Tangibility and Non-debt tax shield to have a positive relationship with equity. The study also discovered that, the size of a bank was a significant determinant of equity and also has a positive association with equity. There was a positive relationship between performance and equity. There was also a negative relation with Growth opportunity of a bank, Dividend policy and equity. Performance and size of a bank are the determinants of leverage. There was a statistically significant positive relation with leverage and a negative statistically significant relation with the size of a bank. The study found Leverage to have positive relationships with Asset Tangibility, Non-debt tax shield and Dividend ratio. The study also discovered a negative association between Growth Opportunity of a bank and Leverage.
\end{abstract}

Keywords: Capital Structure, Equity, Performance, Panel Data, Listed Banks, Ghana

\section{Introduction}

Capital Structure can be defined as the technique a Bank funds its assets by a mixture of equity, debt, or hybrid securities (Abor, 2008). In reality, there is financial risks in taking on too much debt, so each bank must find a balanced structure. Corporate segment progress is essential to economic expansion. The concern of money has been surely understood as a sudden motivation behind why commercial enterprises in developing nations are unsuccessful to begin or to progress. It is intended for Banks in creating nations to be fit for financing their activities and create over a time frame on the off chance that they are to have amassed a driving influence in giving employments and also salary as benefits, dividends and wages to family units (Abor, 2008). Capital Structure choices spotlights on the blend of long haul financing sources utilized by the firm. Accordingly, Capital Structure choices must consider the general financing arrangement of the organization including the utilization of exchange credit.

Interestingly, budgetary structure is a term used to portray the general liabilities and total assets of the firm. That is to say, the monetary structure choice is a financing blend choice and the Capital Structure choice is a piece of it (Myers, 2001). That is the long haul financing part of the general financing choice.

The few studies on developing nations have not set up themselves on the fundamental actualities. Singh and Hamid (1992) used measurements on the biggest firms in assigned creating nations. It was finished up that firms in rising nations made the utilization of outer money to subsidize their improvement than is as a rule in effectively created nations. They further closed by expressing that firms in developing nations will tend to lay on additional equity fund rather than debt finance. These disclosures seem unanticipated given that the advancement of stock markets in such nations is neverendingly less created contrasted with created nations, especially for values. Regardless, a study by Indian scientists, Cobham and Subramaniam (1998) utilized a specimen of bigger firms and subsequently inferred that Indian firms utilize strikingly bring down external and equity financing. In an investigation of expansive organizations in ten creating 
nations, Corner et al. (2001) likewise finished up that debt ratios contrasted significantly with developing nations, however in general, were not out of track with comparative information.

Information of late hypothesis of Capital Structure is the noteworthy commitment of Modigliani and Miller (1958) under the ideal capital business sector supposition. Modigliani and Miller (1958) expected that under state of no bankrupt cost and frictionless capital markets without taxes, a firm's worth is self-governing of its Capital Structure.

A different school of an idea clenches the opinion that funding decision mirrors an effort by business directors to adjust duty protection of more prominent obligation beside potential vast cost of budgetary trouble emerging from less speculation. Yet if much equity debt equity can hammer company's value by bringing on money related trouble and under speculation then too little obligations can additionally prompt excessive investment and undesirably influence earnings especially in extensive and experienced Bank (Barclays and Smith, 2005).

The decision of Capital Structure and its consequent optimal danger presentation is exceptionally overwhelming in financial execution of each bank. This is on account of the decision of capital structure ought to in the long run lead to a result in the improvement in the value of investment made the different gatherings of agents generally equity speculators (Watson and Head, 2007). This is noteworthy in view of the way that equity lenders have prevalent anticipation of incomes on their investment as higher dividends and capital increase (Sulaiman, 2001).

As a developing country, Ghana still has vast untapped human and natural resources. The principle issue however is that capital for investment is inadequate. There has been dependence on outside sources of capital for investment. It has however been observed that if Ghana is to gain any significant ground in financial development, she will have to depend more on her household investment funds. For most Ghanaian financiers, the expected returns of long-term investments are the dividends they receive as well as capital gains. Failure to meet this expectation would result in the sale of shares, which will result in the decline of the company's share price. The drop in share price sends an indication to prospective financiers of the poor presentation of the business by discouraging prospective financiers from financing both in equity stock and debt for most companies, such a reaction will be highly undesirable since a company's share price provides a measure of its performance.

Thus to be able to boost financier confidence and sustain its ability to remain in business, a company must be able to decide on a Capital Structure that best protects shareholder wealth (Modigliani and Miller (1958).

The decision of investment funding, and its relation with optimal risk contact, is vital to the economic performance of every bank. Financial economies have a rich literature scrutinizing the Capital Structure choice in quantitative positions. The basic financial objective of every firm is to take full advantage of the wealth of the existing owners of the firm. For publicly held establishments, this objective translates into maximizing the per share price of the firm's mutual stock. (Booth et al., 2001).

In recent years, Ghana's Presidents have been combing the world looking for funds into the different segments of the economy. The establishment of the stock exchange as part of Ghana's reform towards the development of efficient financial system has exposed firms to more financing options. Additionally all our real state possessed ventures are being stripped to outside owners. This expanded support of outside financiers has suggestion for the execution of the stocks on the Ghana Stock Exchange.

Another mind boggling issue is how best corporations can control profit arrangement as well as picks the right financing mix (i. e. on ideal Capital Structure) that would adequately and proficiently make riches in a developing nation like Ghana's. These are important issues because a low payout ratio may enable the business to conserve funds while a high payout ratio may raise the demand for the company's securities and facilitate inflow of new funds. Unfortunately, in Ghana, most corporations have not fundamentally investigated the focal points to be deduced in genuinely taking a peek at their industry of operation and looking for after a perfect Capital Structure as well as the right benefit plan for their industry of operation.

The overall objective of this research was to examine Capital Structure Dynamics of Listed Banks in Ghana. The specific objectives of the research was to Examine the significance of Bank performance on capital structure; Examine the determinants of equity and their significance; Examine the determinants of leverage and their significance.

Abor (2008) characterizes Capital Structure as exact combination between equity and debt a firm uses to fund its activities. Capital Structure is a standout amongst the most multifaceted zones of business decision making in light of its interrelationship with other money related choice variables (Gitman et al., 2012). It is critical the way Capital Structure is firmly joined with the capacity of Banks to satisfy the cravings of their desires of their shareholders.

Gitman et al (2012) stated that poor Capital Structure choices can produce a high cost of capital, thus lowering the Net Present Values (NPVs) of tasks and making more of them intolerable. Effective Capital Structure decisions can lessen the cost of resource, results in higher NPVs and more satisfactory projects- and thereby growing the value of the firm.

Capital Structure's effect on the profitability of 22 organizations recorded on Ghana Stock Exchange amidst 1998 to 2002 was looked into by Abor (2005). Results unveiled that there is a noteworthy and positive relationship in the middle of Capital Structure and profit for equity . Besides, he expressed that promising partnerships have more dependence on financing through obligation and $85 \%$ being short-term liabilities.

One of the most significant financial areas that administrators should contemplate to increase shareholders capital is the determination of the finest blend of financial 
wealth for the firm. Capital Structure studies have tenaciously increased after some time and still keep on captivating the consideration of researchers with the fundamental reason for figuring out if equity and debt blend is real. The mix of equity and debt will decreases the cost of capital of a firm while enlarging the firm's significance and this is known as optimal Capital Structure. By the way, how associations pick the measure of equity and debt in their Capital Structure mix remains a conundrum.

Frydenberg (2004) discussed further that, in whole and faultless capital markets, study has presented that total firm worth is autonomous of its Capital Structure. An optimal Capital Structure does not exist when capital markets are impeccable. Taxes and other market limitations are critical to housing a progressive theory of Capital Structure. Modifications in Capital Structure profits only stockholders if and only if the worth of the corporation grows. Miller and Modigliani (1958b) composed the seminal article in this field of research.

Using an arbitrage argument the inference of M\&M (1963) proposal is that firms need to utilize extra debt to develop esteem in connection to equity. Miller and Modigliani's two publications had created numerous studies that added to the explanation of the Capital structure puzzle. If a firm can change its market price by a clean financial procedure, the financiers in the firm can take actions that replicate the successive debt position of the firm. These relations would only change the weights of a portfolio and must, in a perfect capital market, provide zero profit. If the market remained efficient enough to eradicate the proceeds for the financiers, any revenue for the firm would be eradicated too. Modigliani and Miller in their original articles Miller and Modigliani (1958b) and Miller and Modigliani (1958a) undertook numerous stern checks.

\section{Theoretical Overview Capital Structure}

Preceding M \& M theory, prevailing prepositions stimulated that financial leverage was used by firm's to enrich their Firms value. Initially, Miller and Modigliani (1958) theorized that firms worth is self-determining of its financial structure; successively in 1963, they took into justification the corporate tax, they highlighted the consequences of profits of the tax shield of debt; identifying that leverage can decrease the fee commitments associated to corporate tax, the researchers standard that Capital Structure is optimal at $100 \%$ liability sponsoring (as it lessens the weighted average price of capital and exploits firm performance and value) Miller and Modigliani (1963). They again disputed that the Capital Structure of a firm should constitute totally of debt because of tax deductions on interest payments.

Modigliani and Miller (1963) wrangled about that the Capital Structure of a firm ought to constitute totally of debt due to duty derivations on interest installments. Yet, Brigham and Gapenski (1996) discoursed that, in idea, the ModiglianiMiller model is tying. In any case, in all actuality, bankruptcy costs is real and these expenses are straightforwardly proportionate to the debt level of the firm. In this way, an ascent in debt level causes a surge in bankruptcy costs. Along these lines, they debate that that a perfect Capital Structure must be accomplished if the expense covering benefits conveys an ascent in debt level is equivalent to the bankruptcy costs.

The ideas have likewise archived the compensations of money related influence in firm support despite bankruptcy costs sidestepping the costs of monetary anguish. These affirmations have controlled to two winning theoretical models by which different speculations are embedded, namely the static trade-off model and the Pecking Order model. Different speculations are free income theory and the agency cost Theory.

\subsection{Static Trade-Off Theory}

By the trade-off theory, companies' seek debt levels that balance the tax advantages of additional debt against the costs of possible costs of debt (Myers, 2001; Faulkender \& Petersen, 2006). Jensen and Meckling (1976) expressed the trade-off theory as the optimal Capital Structure of firms includes the trade-off among the bankruptcy costs and agency costs, the impacts of corporate and individual taxes, and so forth This theory expected that Capital Structure moves towards a perfect impact which is controlled by altering the corporate appraisal saving estimation of commitment and the costs of monetary misery. This idea has been made in various papers. For example DeAngelo and Masulis (1980) and Bradley et al. (1984). In any case, Mill operator (1977) scrutinized their thought; he debated that static trade-off model derives that firms ought to be to a great degree adapted than they really are, as the expense reserve funds of debt seem tremendous while the costs of financial pain seem immaterial. Klaus and Tzenberger (1973) showed that considering the duty points of interest of debt, optimal Capital Structure includes debt funding. Ross (1977) and Leland and Pyle (1977) level headed discussion that debt can be cherished as a ploy for indicating a firm's worth.

\subsection{Pecking Order Theory}

As expressed by the Pecking Order theory, firms will obtain as opposed to radiate equity, when inside created assets streams are inadequate to record capital overheads (Myers 2001). As expressed by Watson and Head (2007), the Pecking Order theory drives in opposition to the idea that firms having unmistakable combination of debt and equity financing abates their rate of capital. This theory postulates that when an enterprise is considering financing its longstanding investment, it has all around portrayed solicitation of slant concerning the wellsprings of record open to it. Fama and French (2002) and Meyers (1984) depict an organization's debt condition as the aggregated results of before investment and capital planning decisions. 
This theory indicates that firms will back their new funding first by using inward fund as their source of asset. On the off chance that inner assets are lacking or difficult to reach they will proceed onward to the utilization of debts that are sheltered, then debts that are dangerous and finally equity as their wellspring of asset. This implies the Pecking Order theory recommends beneficial firms with high profit ought to utilize less debt in their Capital Structure than those with low income earnings (Myers 1984; Myers \& Majluf, 1984).

Myers \& Majluf (1984) wrote that asymmetry information affects the Capital Structure by controlling access to external finance. Baskin (1989) affirmed that information asymmetry do not only limits firm's capability of equity financing, but also restrict access to Retained Earnings as finance source because firms must pay dividends as a signal to both current and prospective shareholders and cannot be adjusted for financing requirements. Another influence of the Pecking Order theory according to Baskin (1989) is a direct cost. The cost of internal financing is absolutely less as there is no dividend payment for the use of Retained Earnings, which successively result in reduced taxes and commissions and on dividends.

Baskin (1987) tested the Pecking Order hypothesis and documented that firms borrow because they need funds and that bankruptcy cost does not restrict borrowing. Once information asymmetry places restrictions on equity financing, debt tends to become the principal incremental source of finance. Frank and Goyal (2003) stated that Pecking Order theory is amongst the dominant theory of corporate leverage, due to adverse selection; firms favor inside finance as opposed to outside finance when funds are required. Rao et al. (2007) analyzed the debt ratio and defined whether an optimal debt ratio subsists or not. Optimal debt ratio is usually defined as the factor that diminishes the cost of doing business for the firm, while getting the most out of the worth of the firm. Furthermore, optimal debt ratio makes the most of the profitability of a firm according to Rao et al. (2007).

\subsection{Free Cash Flow Theory}

This theory conditions that high leverage, when firm's working cash flow is further than its gainful investment prospects, will cause an increase in firm's value notwithstanding its threat of financial distress (Myers, 2001).

\subsection{Agency Cost Theory}

The agency theory originally explained by Berle and Means (1932) also offers theory on Capital Structure choice. From the theory, agency conflicts ascend from the deviation of benefits among investors (principals) and administrators (agents) of firms. The key duty of administrators is to manage the firm to yield return to shareholders thus growing the return statistics and cash flows (Elliot and Elliot, 2002). This theory was additionally exhibited by Jensen and Meckling (1976), stating that firm's Capital Structure ascending from agency costs of interest conflicts between different stakeholders participation. These two researchers identified two types of conflict of interest, namely

i. Conflict of interest between administrators and shareholders, and

ii. Conflict of interest between shareholders and debtors of firm.

According to Jensen and Meckling, by creating a balance between profits of debt, such as tax benefits and agency costs of debt we can achieve to an optimal Capital Structure (Izadinia \& Rasayan, 2010).

\section{Empirical Evidence and Hypothesis Development}

\subsection{Leverage}

The term operating leverage refers to the extent to which fixed operating costs are part of a firm's total operating costs, Watson and Head (2007). Stulz (1990) wrote that for leverage to be relevant for the worth of a firm there has to be case that no clever arbitrageurs can profit from such a situation. Primarily, if market failures are present, tax consideration, asymmetric information, transaction costs and bankruptcy costs factors must be present for leverage to matter. Furthermore, the existence of a possibility to make a trade of the firm with the sub-optimal Capital Structure for the firm with the optimal Capital Structure must be absent.

Given the watched contrasts in the organization of liabilities, before undertaking any examination of influence, it is fitting to characterize what we mean by this term. Obviously, the degree of leverage and the most significant measure relies on upon the investigation's goal. Aghiori and Bolton (1992) focused on leverage as a way of shifting control in bad periods from the hands of investors (or their fiduciaries) to the hands of debtors (or their fiduciaries) Here, the imperative inquiry is whether the firm can meet its settled overheads, and thusly, a stream measure indistinguishable to the interest scope proportion is more applicable. As opposed to investigating every conceivable theory and their related measures of leverage. The agency problems connected with debt Jensen and Meckling (1976), Myers (1977) to a great extent identify with how the firms has been financed in the past and therefore on the near cases on firm esteem held equity and debt. Here, the appropriate quota is probably the stock of debt comparative to firm price.

It must be noted that adding of more fixed costs raises the volatility of net returns to the common stockholders and greater volatility means greater dispersion in their returns or increased risk, Mazzeo (1992).

\subsection{Asset Tangibility}

The natural surroundings of a firm's assets influence Capital Structure. Tangible assets are less subject to information asymmetries and ordinarily they have a more noteworthy quality than Intangible resources in the occasion 
of liquidation. Also, moral hazard risks are abridged when the business offers tangible assets as security, since this consist of a positive sign to the creditor. Banks can auction these benefits in the occasion of default. Hence, the trade-off theory foretells a positive association among measures of leverage and the section of tangible assets (Aviral and Raveesh, 2015).

The degree to which the firm's focal points stay considerable should impact the firm taking more huge bankruptcy regard (Titman and Wessels, 1988; Harris and Raviv, 1991). Bradley et al. (1984) affirm that firms that place energetically in unmistakable assets in like manner require more prominent budgetary impact in light of the fact that they secure at lesser loan fees if their debt is ensured by such assets. It is trusted that debt may be everything except expeditiously used if there are strong focal points for serve as security (Wedig et al., 1988).

Booth et al. (2001) Suggested that the compatibility between generous settled assets and debt funding is recognized by adding to the structure of the debt. In such condition, the level of generous settled assets may help firms to secure more long-term debt; however the office issues might turn out to be more serious with the more unmistakable altered resources, in light of the fact that the data uncovered about future benefit is less in these organizations. If so, it is liable to locate a positive correlation between tangible fixed assets and debt ratio. From the above, it can be hypothesized that:

$H_{1}$ : Asset Tangibility is positively related to Bank's equity and leverage

\subsection{Size of the Bank}

Size is seen as a factor of a bank's Capital Structure Bigger Banks are more enhanced and consequently have lesser fluctuation of income, building them to endure great obligation proportions (Wessels, 1988; Titman and Wald, 1999; Castanias, 1983). Minor Banks, then again, may discover it generally all the more excessive to determine information asymmetries through moneylenders, consequently, may present lower obligation proportions (Castanias, 1983). Creditors to bigger companies will probably get reimbursed than moneylenders to littler firms, decreasing the organization expenses connected with obligation. Hence, bigger banks will have greater obligations. Alternative clarification for littler firms having lesser obligation proportions is if the comparative insolvency costs are an opposite capacity of banks (Titman and Wessels, 1988). The trade-off theory expects a transposed correlation between size and the likelihood of liquidation, i.e., a positive association between size and leverage. Nonetheless, the Pecking Order theory of the Capital Structure expects an inverse association between size and leverage. A bigger corporation displays a growing liking for equity comparative to debt. Based on these assertions, we can hypothesis that:

H2: Size of the Bank is positively related to its equity and leverage

\subsection{Growth Opportunities}

Marsh (1982) stated that corporations with high development will catch moderately higher debt ratios. On account of little firms with more focused proprietorship, this was likewise bolstered by Heshmati (2001), that, high progressive corporations will require more external funding and ought to exhibit greater leverage.

However, the empirical evidence appears indecisive. Various scholars established positive relationships amongst growths opportunities and leverage (Kester, 1986; Titman and Wessels, 1988; Barton et al., 1989). Further suggestion submits corporation's with greater growth opportunities takes into the use of a smaller amount of debt (Kim and Sorensen, 1986; Rajan and Zingales, 1995; Roden and Lewellen, 1995; Al-Sakran, 2001) instituted out that imminent progress is positively related to leverage and long-term debt.

It's additionally imperative that the dividend payout of the firm might influence the optimal select of capital in funding growth. For the most part, firms with small dividend payout have the capacity to hold more returns planned for savings. Such businesses would along these lines rest on inside created stores and less on debt funding. On the other hand, firms with great dividend payout are inclined to be subordinate on debt in solicitation to subsidize their improvement prospects. It is therefore hypothesized that:

H3: Growth Opportunity is negatively associated with Bank's equity and Lever

\subsection{Non-Debt Tax Shield}

The debt tax shield has roused spans in years of deliberation concerning a corporation's estimation and the price of capital. In 1963, Modigliani and Miller first postulated that the tax benefits of debt swells a corporations' worth and reduce the cost of consuming debt capital. In 1977, Miller countered that corporations pass out the tax aids of debt to investors through high intrigue rates to remunerate them for the individual tax detriment of debt. Others have suggested that the money related trouble costs of debt offset a minimum of the tax benefit (see, e.g., DeAngelo and Masulis, 1980). Hence, the corporation's estimation and Capital Structure's repercussions of the debt tax shield are imprecise. It can therefore be hypothesized that;

H4: Non-debt tax shield is positively related to Bank's equity and leverage.

\subsection{Dividend Policy}

Dividend policy the firm's amount of cash it thinks is necessary and appropriate to pay shareholders Ross (2007). The dividend payout ratio is an additional aspect that might have an impact on companies leverage. Starting with the agency and exchange cost contention, organizations with an awesome payout extent will have smaller agency costs of equity, which reinforces organizations to expend additional equity financing Rozeff (1982). There would exist a negative relationship since dispensing dividends is an indication of an anticipated development of approaching income and this is a 
sign to weakening in the cost of equity subsidizing (Antoniou et al., 2008). The customary measure of the benefit payout extent is the extent of benefits to net income, from the above, it can be hypothesized that;

H5: Dividend policy is inversely related to Bank's equity and leverag

\section{Data and Methodology}

\subsection{Data Source and Sample}

Seven (7) Banks listed on the Ghana stock exchange were selected for this study. The data sources used for the research were financial statements of the selected companies' for the period. The balanced sheet and profit and loss accounts for the years in question was used. References were also made to the notes of the numerous accounts for indept explanation as well as secondary data from the listed banks in the Ghana stock exchange. The audited financial statement of the listed banks was used so as to increase the reliability and validity of the findings and conclusions. Further information on each selected Bank's Capital Structure, Return on equity, dividend policy and other relevant information were obtained through Data on Debt- to- equity ratio (Capital Structure), Return on equity and benefit prior and then after tax of chosen banks from the Ghana Stock Exchange, the individual companies and from statistical publications.

The data was taken from annual financial and income statements which cover an 8 year period, thus 2005- 2012 .

\subsection{Variable Construction}

Following (Remmers et al., 1974; Cassar and Holmes, 2003), the 2 dependent variables are equity and leverage. Equity is the bank's total asset less their total liabilities. Leverage can be defined as the portion of the bank's total debt repayable within one year or bank's total debt repayable beyond one year.

The explanatory variable is performance measured by a ratio of return on asset (ROA) to return on equity (ROE). It might be useful to connect with various measures instead of pick a solitary one depending on subjective suppositions about their suitability. Case in point Kuznetsov and Muravyev (2001) utilized work efficiency, productivity, and Tobin's Q as estimations of performance. In this study the researcher deliberated two performance proxies namely return on assets (RoA) and Return on Equity (RoE).

ROA measured by the ratio of net income to total asset. Return on Equity (ROE) calculated by the banks profit after tax divided by the net worth of the bank.

The control variables are included because they also have some effect on the dependent variables, but they are not the subject of interest in the study. These are asset tangibility, size, growth opportunity, Non-debt tax shield and dividend policy.

\subsection{Methods of Data Analysis and Hypotheses Testing}

The study is carried out using a panel data framework.
This is because panel data involves the combining of observations on a cross section of entities over numerous time periods and enables identification of effects that are simply not obvious in pure time-series studies. The panel regression equation varies from a regular time-series or cross section regression by the insertion of the double subscript attached to each variable. The general form of the panel data model can be specified more compactly

$$
Y_{i t=\alpha+\beta X_{i t}+e_{i t}}
$$

The subscript $i$ denotes the cross-sectional measurement and $t$ signifies the time-series element. The variable $\mathrm{Y}_{\mathrm{it}}$ denotes the dependent variable in this model. $X_{i t}$ contain the independent variable which is constant overtime $t$ and specific to the discrete cross-sectional unit $i$.

Pearson correlation and estimation of panel regression models for hypotheses testing were utilized and analyzed. The results were built on statistical centrality or insignificant coefficients. For this tenacity, after determining the technique that shows the most accurate estimate, by the utilization of $\mathrm{t}$ statistic, the specialist test the estimation coefficients of independent variables in the regression models utilized for the hypotheses by the utilization of:

$\mathrm{H} 0: \beta=0$

$\mathrm{H} 1: \beta \neq 0$

H0 hypothesis implies that the independent variable coefficient is zero which therefore implies there exist no relationship among the adjustments in the tested dependent variable and independent variables. $\mathrm{H} 1$ is additionally meaning the association among changes in independent variables and dependent variable. The hypotheses are tested in a $5 \%$ mistake level. 'In the event that the $\mathrm{p}$ value is less $5 \%$, then, the correlation is confirmed at $95 \%$ confidence level and otherwise is rejected.

To decide between fixed or random effects, a Hausman test was conducted where the null hypothesis is that the preferred model is random affects vs. the alternative the fixed effects (Green, 2008). It basically tests whether the unique errors $\left(e_{i t}\right)$ are correlated with the regressors, the null hypothesis is they are not.

\section{Models Specification}

We analyzed two models by way of avoiding a problem of multicollinearity in the estimation models. From the econometric model by Miyajima et al. (2003), because their model presents itself as the most appropriate, we estimate the following specific panel regression model:

$$
\begin{aligned}
& E q t_{i t}=\alpha+\beta_{1} \operatorname{Perf}+\beta_{2} T A N G_{i t}+\beta_{3} S I Z E_{i t}+\beta_{4} G R O W_{i t}+ \\
& \beta_{5} T A X_{i t}+\beta_{6} D I V_{i t}+e_{i t} \\
& \text { lev }_{i t}=\alpha+\beta_{1} \operatorname{Perf}+\beta_{2} T A N G_{i t}+\beta_{3} S I Z E_{i t}+\beta_{4} G R O W_{i t}+ \\
& \beta_{5} T A X_{i t}+\beta_{6} D I V_{i t}++e_{i t}
\end{aligned}
$$

From the model specification, the following equations are estimated, where;

Eqt- equity of firm $i$ in year $t$,

Lev-Leverage of firm $i$ in year $t$,

Perf- Performance of firm $i$ in year $t$, 
Tang-asset tangibility ration of firm $i$ in year $t$,

Size-size of firm $i$ in year $t$,

Grow-growth opportunities of firm $i$ in year $t$,

Tax-non debt tax shield of firm $i$ in year $t$,

Div-dividend policy of firm $i$ in year $t$.

Table 1. Measurement of Variables.

\begin{tabular}{|c|c|c|}
\hline Code & Variable name & Calculating method \\
\hline \multicolumn{3}{|c|}{ Dependent variables } \\
\hline Eqt & equity & Total asset-Total Liabilities \\
\hline Lev & Leverage & Total debt/ Total Asset \\
\hline \multicolumn{3}{|c|}{ Independent variable } \\
\hline Perf & Performance & Return on asset/return on equity \\
\hline \multicolumn{3}{|c|}{ Control variables } \\
\hline Tang & Assets tangibility & Profit before tax/ total assets \\
\hline Size & firm size & $\begin{array}{l}\text { Natural logarithm of total assets of the } \\
\text { firm }\end{array}$ \\
\hline Grow & Growth opportunities & $\begin{array}{l}\text { change in the natural logarithm of total } \\
\text { assets of the firm }\end{array}$ \\
\hline Tax & Non debt tax shield & total asset/tax payment \\
\hline Div & Dividend policy & Dividend ratio/ net income \\
\hline
\end{tabular}

These definitions are in line with previous studies by Cassar and Holmes, 2003; Esperança et al., 2003; Hall et al., 2004; Sogorb-Mira, 2005). All the variables used in this study are based on book value in line with the argument by Myers (1984) that book values are proxies' for the value of assets in place.

\section{Empirical Results}

\subsection{Descriptive Statistics}

Table 2. Summary.

\begin{tabular}{llllll}
\hline Variable & Observation & Mean & Std. Dev. & Minimum & Maximum \\
\hline equity & 56 & $1.09 \mathrm{e}+08$ & $3.22 \mathrm{e}+08$ & -538965 & $2.39 \mathrm{e}+09$ \\
leverage & 56 & .9838564 & 1.143439 & .0008698 & 9.2658 \\
perf & 56 & .6321214 & 1.462195 & .0028 & 6.3384 \\
tang & 56 & .044725 & .0291979 & .0053 & .2102 \\
size & 56 & 17.12038 & 3.557022 & 11.2378 & 21.8125 \\
grow & 56 & .6883929 & 1.312046 & -1.8203 & 5.1917 \\
tax & 56 & 195.5144 & 406.9835 & 17.0593 & 2852.142 \\
div & 56 & .2579768 & .1836789 & 0 & .8103 \\
\hline
\end{tabular}

Source: Author's computation

The summary of the statistics used in this empirical study is presented. The mean and standard deviation of all the variables over the sample period. It also reports the minimum and maximum score of both the dependent and the independent variables. The mean value of Equity is 1.09 with maximum and minimum score of 2.39 and -538965 respectively. The Mean, maximum and minimum score of leverage is $0.98,9.2658$ and.0008698 respectively. Performance had a mean score of 0.63 , maximum score of 6.34 and a minimum score of 0.0028 . The Mean, of Asset tangibility, size, Growth, Non-debt tax shield and dividend ratio is $0.044,17.12,0.688 ., 195.54$ and 0.257 respectively.

\subsection{Regression Results and Discussion}

\subsubsection{Equity Analysis}

The study performed a panel analysis using a fixed effect and random effect. The fixed effect had a p-value of $24.27 \%$ while the Random effect had a P-value of $0.80 \%$ showing that the random effect is significant and presents the output for Equity using the Random effect.

Table 3. Equity.

\begin{tabular}{llll}
\hline EQUITY & COEFFIENT & STANDARD ERROR & P-VALUE \\
\hline Perf & $3.16 \mathrm{e}+07$ & $3.06 \mathrm{e}+07$ & 0.301 \\
Tang & $1.68 \mathrm{e}+09$ & $1.56 \mathrm{e}+09$ & 0.280 \\
Size & $3.63 \mathrm{e}+07$ & $1.24 \mathrm{e}+07$ & $0.003^{*}$ \\
Grow & $-2.85 \mathrm{e}+07$ & $3.11 \mathrm{e}+07$ & 0.361 \\
Tax & 42033.2 & 104739.8 & 0.688 \\
Div & $-4.12 \mathrm{e}+08$ & $2.27 \mathrm{e}+08$ & $0.070^{* *}$ \\
const & $-4.90 \mathrm{e}+08$ & $2.29 \mathrm{e}+08$ & 0.033 \\
\hline
\end{tabular}

Source: Author's computation

*Indicates 5\% significance figure

$* *$ indicates $10 \%$ significance figure

Equity has a positive relationship with Performance, Asset Tangibility, and Size of the firm and Non-debt tax shield. This implies that as performance, asset tangibility and size of the firm increases, then the firms' worth also increases. This result indicated that a high performing firm will have its equity greater than a low performing firm.

Equity is also negatively related with dividend and the growth opportunity of the firm. This implies that a bank with low equity has the opportunity to grow higher than a bank with high equity. A bank pays dividend out of its worth so when the dividend is paid, the bank's worth reduces.

At $95 \%$ confidence interval, we can clearly say, Size of the Bank is highly significant and therefore a major determinant of equity of listed banks in Ghana.

\subsubsection{Leverage Analysis}

The study performed a panel analysis using a fixed effect and random effect. The fixed effect and the random effect both gave a p-value of $0 \%$ so the Hausman Test was run. The test failed to meet the asymptotic assumptions of the Hausman test, therefore, the study choose the random effect.

Table 4. Leverage.

\begin{tabular}{llll}
\hline LEVERAGE & COEFFIENT & STANDARD ERROR & P-VALUE \\
\hline Perf & -.2472246 & .0682926 & $0.000^{*}$ \\
Tang & 37.00682 & 3.478571 & $0.000^{*}$ \\
Size & .0473832 & .0276039 & $0.086^{* *}$ \\
Grow & -.038958 & .0695303 & 0.575 \\
Tax & .0003365 & .0002338 & 0.150 \\
Div & .5649112 & .5073069 & 0.265 \\
const & -1.510914 & .5111185 & 0.003 \\
\hline
\end{tabular}

Source: Author's computation

*Indicates 5\% significance figure

**indicates $10 \%$ significance figure

Leverage has a positive relationship with asset tangibility, size of the firm, Non-debt tax shield and dividend policy. As asset tangibility, Non-debt tax shield and dividend policy increases, the leverage (total debt) of the Bank increases. Performance and asset tangibility was highly significant in determining a listed Bank's leverage.

Size of the firm's coefficient for leverage is positive and 
significant at $90 \%$ confidence interval, the outcomes is in track with Harris and Raviv (1991) and Rajan and Zingales (1995). The outcomes recommend that bigger banks with greater assets' tangibility employ more leverage to influence and accomplish the tax benefits of debt, as bigger banks face fewer risk of bankruptcy.

The results showed that performance and growth opportunity has a negative relationship with leverage. This is in line with the studies by to Titman \& Wessels (1988), Rajan and Zingales (1995), Harris \& Raviv (1991), Ghosh et al. (2000) and Booth et al (2001) with an with a reverse relationship between growth and leverage.

The results indicate a positive relationship amongst tax and leverage. The positive coefficient could be attributable to the added tax levied on banks. In Ghana, banks are taxed a special tax and the tax rise would be allied with the amassed debt capital. This was affirmed by Amidu (2007).

The positive coefficient of dividend policy, show that when a bank has a policy to pay profit, it impacts on its performance. This is in accordance with the confirmation of profit hypothesis by John and William (1985) and Miller and Rock (1985) that dividend policy influences a firm share price.

The Performance was only significant in determining the leverage of the listed banks. There was a negative relationship between the performance of a bank and its leverage (Debt). It implies that an increase of $100 \%$ in leverage was due to a fall of $24.72 \%$ in performance. Banks which perform better usually have low debt stock. Logically it implies that when Banks perform better, there earn more revenue and therefore plough back their profit so they tend to borrow less.

Size was only a determinant of equity. There exist a positive association between size and equity. Intuitively, as the size of a bank increases, the equity of that bank increases. Therefore, the size of a bank does not only influence bank equity positively but also significantly.

Dividend policy was also significant at $90 \%$ confidence interval.. However, there was a negative relationship between equity and dividend policy. Intuitively, since dividend was paid out of a banks profit, an increase in dividend adversely affected the worth and equity of the bank.

Performance and asset tangibility of a bank are the highly significant determinants of the leverage of a bank. A 5\% confidence interval indicate a highly significantly positive association between Asset Tangibility and leverage and a highly negative significance with performance the significantly positive regression coefficient for total debt.

Also, the negative coefficient of performance suggests that Performing Banks depends less on debt as their main financing option. Therefore, this hypothesis shows that there exist a significant but negative correlation among leverage and a bank's performance. The results of this speculation is unfaltering with the examination consequences of Onaolapo and Kajola (2010), Houang and Song (2006), and Zeitun and Tian (2007), yet is changing with the exploration aftereffects of Aburub (2012).
The significantly and positive regression coefficient association between total debt and asset tangibility implies that an increase in the debt position is allied with an increase in asset tangibility. Thus, the higher the debt the greater tangible asset, which confirms that greater assets' tangibility is allied with higher leverage. This result is fortified likewise by the audit of Measurements New Zealand (2004), that more than $70 \%$ of New Zealand Banks use debt funding. The huge result for tangibility in elucidating debt settles that guarantee is of significance for banks to secure utilization of debt.

\section{Conclusion and Recommendation}

This study examines capital structure Dynamics of listed Banks in Ghana from 2005 to 2012 consisting of a panel model composing of fixed and random effects. In this study from Asset Tangibility (Tang), Size of the Bank (Size), Growth Opportunity (Grow), Non-debt tax shield (Tax), Dividend Policy (Div) as constituents of capital structure and the financial performance of Banks measured as return on assets (ROA) divided by return on equity (ROE) as means of accessing the banks Performance.

The elementary remark made was that the mean of the capital structure of the Banks recorded on the Ghana Stocked Exchange was $98 \%$ over the period for assessment suggesting that banks listed in Ghana are extremely geared. This implies that for $\mathbb{C} 100.00$ available for operating a business, $\mathbb{C} 98.00$ would be financed by debt and the remaining $\mathbb{C} 2.00$ by equity. This therefore can be attributed to banks over reliance on leverage as an outcome comparatively due to high Central Bank's Lending rate and the low level of activities of bond market in Ghana.

Furthermore, the results of this study have given some comprehension on the capital structure of Ghanaian Banks. The subject of the mix of debt and equity is an essential strategic funding choice that banks need to make. Obviously, the Static trade off theory seems to overwhelm the Ghanaian capital structure story of listed Banks this implies that profitable and performing Ghanaian listed Banks use more debt because they operate based on external funding.

Also, empirical evidence from this studies suggest that, Performance, Size of a Bank and Asset tangibility are the most important variables that influence Banks capital structure in Ghana.

\section{Recommendations}

Based on the findings of this research, some recommendations were made as follows:

Government should pursue policies to bring down the rate of depreciation of the cedi, as well as reduce the level of inflation against that of the developed countries to prevent the banks from being highly geared.

Since performance is significant in determining leverage, lending firms and banks should be wary and cautious when borrowing to a highly geared firm since they don't perform better and might not be able to pay 
Also, the government must also endeavor to promote the reduction of the Bank of Ghana's Lending Prime Rate so that the banks can easily lend among themselves.

Furthermore, it is very rewarding when a business organization is able to reach its optimal capital structure and is therefore significant for financial managers to pursue the exact optimal capital structure that will contribute to their shareholders maximizing returns on their investments.

\section{Refrences}

[1] Abor, J. and Biekpe, N. (2005). "What determines the capital structure of listed firms in Ghana?" African Finance Journal, 7 (1), $37-48$.

[2] Abor, J. (2005). The Effect of Capital Structure on Profitability: "An Empirical Analysis of Listed Firms in Ghana". The Journal of Risk Finance, 6 (5), 438-445. http://dx.doi.org/ 10. 1108/15265940510633505

[3] Abor, J. (2007). "Industry Classification and the Capital Structure of Ghanaian SMEs" Studies in Economics and Finance, 24 (3), $207-219$.

[4] Abor, J. (2008). Determinants of the Capital Structure of Ghanaian Firms. Research Paper No. 176. African Economic Research Consortium, Nairobi. Retrieved from http:// dspace.cigilibrary.org/ jspui/ bitstream/ 123456789/32100/1/ RP 176. pdf

[5] Aburub, N. (2012). Capital Structure and Firm Performance: Evidence from Palestine Stock Exchange. Journal of Money, Investment and Banking, 23, 109-117.

[6] Aghion, P. and Bolton, P. (1992). An Incomplete Contract Approach to Financial Contracting, Review of Economic Studies 59: 473-494.

[7] Al-Sakran, S. A. (2001). "Leverage determinants in the absence of corporate tax system: The case of non-financial publicly traded corporations in Saudi Arabia". Managerial Finance, 27 (10/11): 58-86.

[8] Amidu, M. (2007). "Determinants of Capital Structure of Banks in Ghana: an empirical approach" Baltic Journal of Management. 2 (1), 67-69.

[9] Antoniou, A., Guney, Y. and Paudyal, K. (2008). "The Determinants of Capital Structure: Capital Market-Oriented versus Bank-Oriented Institutions", Journal of Financial and Quantitative Analysis, vol. 43, no. 1, pp. 59-92.

[10] Aviral K. L. And Raveesh, K. (2015). "Determinants Of Capital Structure: A Quantile Regression” Analysis Studies in Business and Economics no. 10 (1)

[11] Awunyo-Vitor, D. and Badu. J. (2012). Capital Structure and Performance of Listed Banks in Ghana Volume 12 Issue 5 Version 1.0 March 2012 Global Journal of Human Social Science

[12] Barclays, M. And Smith, C. (2005). "Capital Structure Puzzle: The Evidence Revised", Journal of Applied Corporate Finance, 17 (1), 8-17.

[13] Barton, S. L., Ned, C. H. and Sundaram, S. (1989). "An empirical test of stakeholder theory predictions of capital". Financial Management, 18 (1): 36-44.
[14] Baskin, J. (1989). An Empirical Investigation of the Pecking Order Hypothesis Financial Management, 18 (1), 26 - 35.

[15] Berle, A. A and Means, G. C. (1932). The Modern Corporation and Private Property. New York, Macmillan.

[16] Booth, L., Aivazian, V., Demirguc-Kunt, A. and Maksimovic, V. (2001). "Capital structures in developing countries". Journal of Finance, 55 (1): 87-130.

[17] Boundless. (2015). "Benchmarking." Boundless Finance. Boundless, 21 Jul. 2015. Retrieved 29 Jul. 2015 from https://www.boundless. com/finance/ textbooks/ boundlessfinance-textbook/ analyzing- financial-statements-3/usingfinancial-ratios-for-analysis-45/benchmarking-227-8303

[18] Bradley, M., Jarrel, G. A. and Han Kim, E. (1984). On the Existence of an Optimal Capital Structure: Theory and Evidence. The Journal of Finance, 39, 857-880. http://dx.doi.org/ 10.1111/j.1540-6261.1984.tb 03680.x

[19] Brealey, R. A., Stewart, C M. and Alan, J M. (2004). Fundamentals of Corporate Finance. Boston, Mass.: McGraw-Hill Irwin, Brigham, E. and Gapenski, L. (1996): Financial Management. Strategic Management Journal, 17, pp $713-728$.

[20] Brounen, D., De Jong, A. and Koedijk, K. (2006). Capital structure policies in Europe: Survey evidence. Journal of Banking \& Finance, 30, 1409-1442. Business Finance in New Zealand 2004.(2004). Statistics New Zealand.

[21] Cassar, G. and Holmes, S. (2003), "Capital structure and financing of SMEs: Australian evidence", Journal of Accounting and Finance, Vol. 43 No. 2, pp. 123-47.

[22] Castanias, R. (1983). "Bankruptcy risk and optimal capital structure". The Journal of Finance, 38: 1617-35.

[23] Chen, Y., Huang Y. and Chen, C. (2009). Financing Constraints, Ownership, Control, and Cross-Border M\&As: Evidence from Nine East Asian Economies. Corporate Governance: An International Review, 17 (6), 665 - 680.

[24] Cobham, D. and Subramaniam, R. (1998). "Corporate finance in developing countries: New evidence for India". World Development, 26 (6): 1033-47.

[25] Copeland, T. F. and Weston, F. (1988). Financial theory and corporate policy. Addison Wesley, Third edition, DeAngelo, H. and Masulis, R. W. (1980). "Optimal Capital Structure under Corporate and Personal Taxes". Journal of Financial Economics, 8, 3-29.

[26] Elliot, B. and Elliot, J. (2002). Financial Accounting and Reporting. $12^{\text {th }}$ Edition, London, Prentice Hall/ Financial Times.

[27] Esperança, J. P., Ana, P. M. G. and Mohamed, A. G. (2003). "Corporate debt policy of small firms: An empirical (re) examination". Journal of Small Business and Enterprise Development, 10 (1) 62-80.

[28] Fama, E. F. and French, K. R. (2002). "Testing Trade-Off and Pecking Order Predictions about Dividends and Frydenberg". Stein (2004). Theory of Capital Structure - A Review, Page 23.Ghana. The Journal of Risk Finance, 6 (5), 438-445. http://dx.doi.org/ 10.1108/ 15265940510633505

[29] Faulkender, M. and Petersen, M. A. (2006). Does the Source of Capital Affect Capital Structure? The Review of Financial Studies, 19 (1), 45-79. 
[30] Frank, M. and Goyal, V. (2003). "Testing the pecking order theory of capital structure". Journal of Financial Economics, 67, 217-248.

[31] Ghosh, A., Cai, F. and Li, W. (2000). The determinants of capital structure. American Business Review, 18, 129-32.

[32] Gitman, J. L. and Zutter, J. C. (2012). Principles of Managerial Finance ( $13^{\text {th }}$ Edition).

[33] Hall, G. C., Hutchinson, P. J. and Michaelas, N. (2004). "Determinants of the capital structures of European SMEs". Journal of Business Finance and Accounting, 31 (5/6): 71128.

[34] Harris, M. and Raviv, A. (1991). The theory of capital structure. Journal of Finance, 39, 127 - 145.

[35] Heshmati, A. 2001. "The dynamics of capital structure: Evidence from Swedish micro and small firms". Research in Banking and Finance, 2: 199-241.

[36] Hoggett, J. and Edwards, L. (2000), Accounting in Australia, John Wiley \& Sons, Sydney.

[37] Houang, G. and Song, F. S. (2006). The Determinants of Capital Structure: Evidence From China. China Economic Review, 14, 14-36. http://dx.doi.org/10.1016/j. chieco.2005.02.007

[38] Izadinia, N. and Rsayyan, B. (2008). Capital structure and corporate income tax in Iran Quarterly Journal of Taxation, 4 (2), 31-43.

[39] Jensen, M. and Meckling, W. (1976). "Theory of the firm: Managerial behavior, agency costs and ownership structure". Journal of Financial Economics, 3: 305-60.

[40] Jensen, M. C. (1986). Agency costs of free cash flow, corporate finance, and takeovers, Small Business Economics, Vol. 8, no. 2 pp. 59-67.

[41] Jermias, J. (2008). "The relative influence of competitive intensity and business strategy on the relationship between financial leverage and performance", British Accounting Review, Vol. 40, pp. 71-86.

[42] John, K. and Williams, J. (1985). "Dividends, dilution, and taxes: a signaling equilibrium", Journal of Finance, 40, 1053-1070.

[43] Kemsley, D. and Nissim, D. (2002). The Journal of Finance, Vol. 57, No. 5 pp. 2045-2073.

[44] Kester, W. C. (1986). "Capital and ownership structure. A comparison of the United States and Japanese manufacturing corporations". Financial Management, 15: 5-16.

[45] Kim, W. S. and Sorensen, E. H. (1986). "Evidence on the impact of the agency costs of debt on corporate debt policy". Journal of Financial and Quantitative Analysis, 21: 131-43.

[46] Kraus, A and Litzenberger, R. (1973). "A State Preference Model of Optimal financial Leverage”. Journal of Finance, 28: 911-922.

[47] Lintner, J. (1954). 'Distribution of Income of Corporations among Dividends, Retain Earnings and Taxes', American Economic Review, May 1956.

[48] Marsh, P. (1982). "The choice between equity and debt: An empirical study". Journal of Finance, 37 (1): 121-44.

[49] Mazzeo, M. A. (1992). 'Capital Structure Implications and M\&M Propositions Working Paper', July 1992, Journal of Business Vol. 65 pp. 353-369.

[50] Merton, R. C. (1990). Continuous-time finance. Basil Blackwell.

[51] Michaelas, N., Chittenden, F. and Poutziouris, P. (1999). "Financial policy and capital structure choice in UK SMEs: Empirical evidence from company panel data". Small Business Economics 12: 113-30.

[52] Miller, M. H. (1977). Debt and Taxes. Journal of Finance, 32, 261-76. http:// dx. doi. org/ 10.1111/j.1540-6261.1977.tb 03267.x

[53] Miller, M. H. and Rock, K. (1985), "Dividend policy under asymmetric information", Journal of Finance, 40, 10311051.

[54] Miller, Merton and Modigliani, Franco. Corporate Income Taxes and the Cost of Capital: A correction. American Economic Review, 48: 261-297, 1958a.

[55] Miller, Merton and Modigliani, Franco. The Cost of Capital, Corporation Finance, and the Theory of Investment. American Economic Review, 48: 261-297, 1958 b.

[56] Miyajima, H., Omi, Y. and Saito, N. (2003). Corporate governance and firm performance in twentieth century Japan. Bus. Econ. History, 1: 1-36.

[57] Modigliani, F. and Miller, M. (1958). "The Cost of Capital, Corporation Finance and the Theory of Investment", the American Economic Review, Vol. 48, 261-297.

[58] Modigliani, F. and Miller, M. H. (1963). Corporate Income Taxes and the Cost of Capital. American Economic Review, 53 (3), 433-443. Retrieved from http:// www2. bc.edu/ $\sim$ chemmanu/phdfincorp/MF891\%20papers/MM1963.pdf

[59] Modigliani, F. and Miller, M. H. (1958). The cost of capital, corporation finance and the theory of investment. American Economic Review, 68 (3), 261-97.

[60] Myers, S. (2001). "Capital structure”. Journal of Economic Perspectives, 15, 81-102.

[61] Myers, S. and Majluf, N. (1984). "Corporate financing and investment decisions when firms have information that, investors do not have". Journal of Financial Economics, 13, 187-221.

[62] Myers, Stewart C. (1984). "The Capital Structure Puzzle”. The Journal of Finance, XXXIX: 575-592, Onaolapo, A. A. and Kajola, S. O. (2010). Capital Structure and Firm Performance: Evidence from Nigeria. European Journal of Economics, Finance and Administrative Sciences, 25, 70-82.

[63] Ooi, J. (1999). "The determinant of capital structure: Evidence on UK property companies". Journal of Property Investment and Finance, 17 (5): 464-80.

[64] Petersen, M. A. and Rajan, R. G. (1994). "The benefits of lending relationships: Evidence from small business data". The Journal of Finance, 49 (1): 3-38.

[65] Rajan, R. G. and Zingales, L. (1995). What do we know about capital structure? Some evidence from international data. The Journal of Finance, 50 (5), 1421-1460. 
[66] Ramaswamy, K. (2001), "Organizational ownership, competitive intensity, and firm performance: an empirical study of the Indian manufacturing sectors", Strategic Management Journal, Vol. 22, pp. 989-98.

[67] Rao, N. V., Al-Yahyaee, K. H. M. and Syed, L. a. M. (2007) "Capital structure and financial performance: Evidence from Oman." Indian Journal of Economics and Business, 6 (1), 4564.

[68] Reilly, F. K. And Brown, K. C. (2006). Investment Analysis and Portfolio Management. $10^{\text {th }}$ Edition New Delhi: CENGAGE Learning.

[69] Remmers, L., Stonehill, A. and Wright, R. (1974). "Beekhuisen industry size as debt ratio determinants in manufacturing internationally", Financial Management, pp. 24-32, (summer).

[70] Roden, D. M. and Lewellen, W. G. (1995). "Corporate capital structure decisions: Evidence from leverage buyouts". Financial Management, 24: 76-87.

[71] Ross, W. J. (2007), Fundamentals of Corporate Finance, $8^{\text {th }}$ edition, pg. 90.

[72] Rozeff, M. S. (1982), "Growth, Beta and Agency Costs as Determinants of Dividend Payout Ratios", Journal of Financial Research, vol. 5, no. 3, pp. 249.

[73] Scherr, F. C., T. F. Sugrue and Ward, J. B. (1993). "Financing the small firm start-up: Determinants of debt use". The Journal of Small Business Finance, 1 (1): 17-36.

[74] Singh, A. (1995). Corporate Financial Patterns in Industrializing Economies: A Comparative Study. IFC Technical Paper No. 2. International Finance Corporation, Washington, D. C

[75] Singh, A. and Hamid, J. (1992). Corporate Financial Structures in Developing Countries. IFC Technical Paper No. 1. International Finance Corporation, Washington, D. C.

[76] Sogorb-Mira, F. and How, S. M. E. (2005). "uniqueness affects capital structure: evidence from a 1994-1998 Spanish data panel”, Small Business Economics, Vol. 25 No. 5, pp. 447-57.
[77] Stiglitz, J. E. (1974). On the irrelevance of corporate financial policy. The American Economic Review, December 1974: 851-866,

[78] Stulz, R. (1990). "Managerial discretion and optimal financial policies". Journal of Financial Economics, 26: 3-27.

[79] Stulz, R., Merton, M. M. and Modern Finance. (1990). Keynote address, Financial Management Association Meetings, Seattle, October 2000, pages 3-25.

[80] Sulaiman, M. A. Al-Sakran, (2001). "Leverage Determinants in the Absence of Corporate Tax System: The Case of Nonfinancial Publicly Traded Corporations in Saudi Arabia" Managerial Finance 27, $261-275$.

[81] Timan, S. and Wessels, R. (1988). "The determinants of capital structure choice, Journal of Finance”, Vol. 43, no. 1, pp. 1-19.

[82] Titman, S. and Wessels, R. (1988). The determinants of Capital structure choice. Journal of Finance, 43 (1), 1-19.

[83] Vance, D. I. (2003). 'Financial Analysis and Decision Making: Tools and Techniques to Solve Financial Problems and Make Effective Business Decisions'.

[84] Wald, J. K. (1999). "How firm characteristics affect capital structure: An international comparison” Journal of Financial Research, 22: 161-87.

[85] Watson, D. and Head, A. (2007). Corporate FinancePrinciples and Practices, $4^{\text {th }}$ Ed., FT Prentice Hall, UK.

[86] Wedig, G., Sloan, F. A., Assan, M. and Morrisey, M. A. (1988). "Capital structure, ownership, and capital payment policy: The case of hospitals". The Journal of Finance, 43: 21-40.

[87] Weston, J. and Copland, T. (1989). Managerial Finance, $8^{\text {th }}$ edition page. 646-649.

[88] Wilson, C. and Keers, B. (1987). Introduction to Financial Management, Prentice-Hall, Sydney.

[89] Zeitun, R. and Tian, G. G. (2007). Capital structure and corporate performance: evidence from Jordan. The Australasian Accounting Business \& Finance Journal, 1 (4), 40-61. 